\title{
Erratum to: Perineal sarcoid in a Caspian miniature horse
}

Mehdi Sakha $\cdot$ Saeed Ozmaie •

Iraj Sohrabi-Haghdoost • Pejman Mortazavi •

Alireza Jahandideh • Mehrdad Ameri

Published online: 13 May 2011

(C) Springer-Verlag London Limited 2011

\section{Erratum to: Comp Clin Pathol}

\section{DOI 10.1007/s00580-011-1201-z}

The correct address of the affiliation for authors M. Sakha, S. Ozmaie, A. Jahandideh, I. Sohrabi-Haghdoost and P. Mortazavi is shown below:

Science and Research Branch, Islamic Azad University

The online version of the original article can be found at http://dx.doi. org/10.1007/s00580-011-1201-z.

M. Sakha $(\bowtie) \cdot$ S. Ozmaie $\cdot$ A. Jahandideh

Department of Clinical Science, Faculty of Specialized Veterinary

Science, Science and Research Branch, Islamic Azad University,

Tehran, Iran

e-mail:msakha@yahoo.com

I. Sohrabi-Haghdoost $\cdot$ P. Mortazavi

Department of Pathology, Faculty of Specialized Veterinary

Science, Science and Research Branch, Islamic Azad University,

Tehran, Iran

M. Ameri

Drug Safety Research and Development, Pfizer Inc.,

Groton, CT, USA 